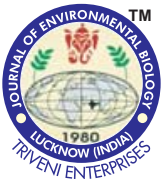

\title{
Influence of salinity variations on exocellular polysaccharide production, biofilm formation and flocculation in halotolerant bacteria
}

Authors Info

B.H. Hong', M.M Joe ${ }^{1,3}$ G. Selvakumar', K.Y. Kim', J.H. Choi ${ }^{2}$ and T.M. Sa*

'Department of Environmental and Biological Chemistry, Chungbuk National University, Cheongju, Chungbuk, 361763 , Republic of Korea

${ }^{2}$ Department of Food Science and Biotechnology, Wonkwang University, Iksan, 54538, Korea

${ }^{3}$ Department of Microbiology, School of Life Sciences, VELS University, Chennai-600 117, India

${ }^{*}$ Corresponding Author Email : tomsa@chungbuk.ac.kr

Key words

Biofilm,

Exopolysaccharide,

Flocculation,

Halotolerant bacteria,

Salinity

Publication Info

Paper received : 04.03.2016

Revised received: 14.11.2016

Accepted : 22.12.2016

\section{Abstract}

Aim: The present study was carried out to evaluate the exopolysaccharide (EPS) production, biofilm formation and flocculation in four halotolerant plant growth promoting (PGP) bacterial strains i.e., Brevibacterium iodinum RS16, Micrococcus yunnanensis RS222, Bacillus aryabhattai RS341, B. licheniformis RS656 under different salt levels.

Methodology: Four halotolerant plant growth promoting bacterial strains namely $B$. iodinum RS16, $M$. yunnanensis RS222, B. aryabhattai RS341 and B. licheniformis RS656 were studied for their exopolysaccharide (EPS) production, biofilm formation and flocculation efficiency under different $\mathrm{NaCl}$ levels. EPS production of halotolerant plant growth promoting strains was quantified in terms of dry weight and glucose content. Biofilm formation of the plant growth promoting halotolerant strains was quantified based on a micro titer plate assay. Plant growth-promoting efficiency of halotolerant strains was quantified in red pepper plants in terms of vigor index and fresh weight.

Results: Among the strains, strain B. aryabhattai RS341 recorded the highest EPS dry weight $\left(5.80 \mathrm{~g} \mathrm{I}^{-1}\right)$, while the highest floc yield $(0.60 \mathrm{~g} \mathrm{l}$ dry weight) was recorded by $B$. licheniformis RS656 at $2 \mathrm{mM} \mathrm{NaCl}$ concentration. Regression analysis revealed that EPS content, expressed in terms of dry weight, and flocculation in terms of floc yield, correlated positively with $\mathrm{NaCl}$ levels. The highest biofilm formation in Canola root surfaces was observed in the strain B. iodinum $\mathrm{RS} 16$ in all $\mathrm{NaCl}$ concentrations. All the halotolerant strains promoted plant growth as evidenced by the increased vigor index and fresh weight irrespective of the level of $\mathrm{NaCl}$.

Interpretation: It was observed that halotolerant bacterial strains were able to promote plant growth in the presence of $\mathrm{NaCl}$ through the mechanisms of EPS production, flocculation and biofilm formations.

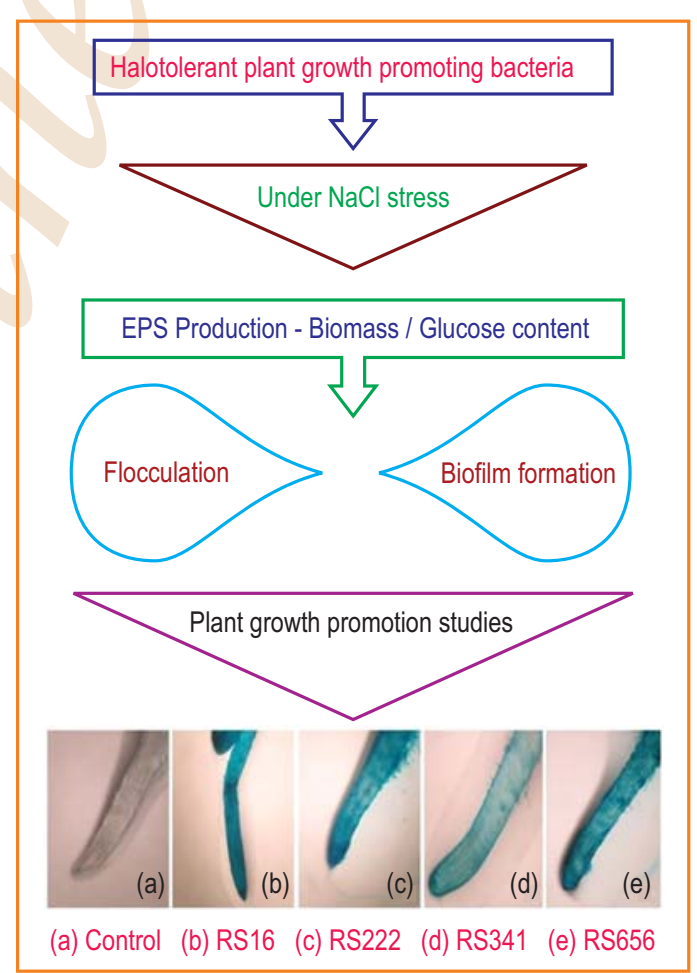




\section{Introduction}

Soil salinity is one of the major factors affecting agricultural productivity in the world and especially in arid and semiarid regions (Ranjbar and Jalali, 2016).Salinity refers to the presence of excessive sodium ions at the root surface leading to the inhibition of plant growth and the excess of $\mathrm{Na}^{+}$ions disrupts plant potassium uptake, which is considered to be a critical factor in plant metabolism (Tester and Davenport, 2003). Some plant growth promoting halotolerant bacteria such as Anabaena torulosa, Serratia proteamaculans and Rhizobium leguminosarum are able to thrive under salt stress conditions and are able to promote plant growth (Upadhyay et al., 2011; Nanjani and Soni, 2012). The reason for this is that the growth of halotolerant bacteria is often accompanied by the production of exocellular polysaccharides, which possess numerous ecological and physiological functions (Ashraf et al., 2005).

EPS helps to protect the bacteria from inhospitable conditions, thereby enabling their survival (Vurukonda et al., 2016). EPS is essential for flocculation or aggregation formation in bacteria, which can be explained as specific adsorption of polymeric segment and polymer bridging between cells (Tenney and Stumm, 1965).Flocculation in bacteria, as a response to salinity, helps the bacteria to survive in stressed environments, and this further helps the host plant against various stresses (Qurashi and Sabri, 2012a). Moreover, EPS play a major role in the formation of bacterial biofilm, which plays a critical role in bacterial colonization on plant root surfaces (Chen et al., 2013).

Taking all these factors into account, the present study was carried out to assess the effect of salinity on EPS production in terms of dry weight and glucose content. The biofilm formation, flocculation and plant growth promoting efficiency of halotolerant bacterial strains (Brevibacterium iodinum RS16, Micrococcus yunnanensis RS222, Bacillus aryabhattai RS341, B. licheniformis RS656) were also evaluated at different salinity levels.

\section{Materials and Methods}

Plant growth promoting halotolerant bacteria and their growth condition : Four plant growth promoting halotolerant bacterial strains viz., B. iodinum RS16, M. yunnanensis RS222, $B$. aryabhattai RS341 and $B$. licheniformis RS656, used in the present study were previously isolated from the coastal saline region of the Yellow Sea, Incheon, South Korea (Siddikee et al., 2011; Siddikee et al., 2012) and these isolates were able to grow in the presence of $1.75 \mathrm{M}(\sim 10 \%) \mathrm{NaCl}$ concentration.

Bacterial EPS production : For quantitative analysis of bacterial EPS production, tryptic soy broth (TSB) with different concentrations of $\mathrm{NaCl}(0,0.5,1,1.5,2 \mathrm{M})$ were inoculated with $24 \mathrm{~h}$ bacterial culture ( $>7 \mathrm{Log}$ CFU $\left.\mathrm{ml}^{-1}\right)$ and incubated in a shaking incubator (DS-310RL, Dasol, Korea) at $30^{\circ} \mathrm{C}, 150 \mathrm{rpm}$ for $72 \mathrm{~h}$ To extract EPS, the above-mentioned cultures were centrifuged at $10000 \mathrm{rpm}$ for $15 \mathrm{~min}$ at $4{ }^{\circ} \mathrm{C}$. To this supernatant, three volumes of pre-chilled ethanol $(95 \%)$ were used to precipitate the EPS. This precipitated EPS was separated by centrifugation at $15000 \mathrm{rpm}$ for $20 \mathrm{~min}$. For determining dry weight, the EPS was dried at $58^{\circ} \mathrm{C}$ for $24 \mathrm{~h}$ in the same centrifuge tube to minimize the EPS loss. The amount of EPS was calculated in terms of dry weight following to the methods of Verhoef et al. (2003) and De Vuyst et al. (1998) and quantified in terms of total carbohydrate content (DuBois et al., 1956).

Biofilm formation experiments : A microtiter plate based protocol was used for the estimation of biofilm formation, with minor modifications (Christensen, 1985). The halotolerant bacterial strains were initially grown at $30^{\circ} \mathrm{C}$, for $24 \mathrm{~h}$ in TSB medium with different concentrations of $\mathrm{NaCl}(0,0.5,1,1.5,2 \mathrm{M})$. The cells were harvested and re-suspended in the same medium and adjusted to $\mathrm{OD}_{600}$ of 0.3 in a spectrophotometer (UV-1601, Shimadzu, Japan). Two hundred microlitre of the re-suspended bacterial suspension was added to each well on a flat-bottomed 96-well microtiter plate and incubated at $30^{\circ} \mathrm{C}$ for $72 \mathrm{~h}$, without shaking. After $72 \mathrm{~h}$, the medium was then removed from the wells and the biofilms formed on the wall of microtiter plates were stained with $0.01 \%$ crystal violet for $20 \mathrm{~min}$. The dye that had stained the bacteria present in the biofilm was then dissolved in $200 \mu l$ ethanol $(95 \%)$, and the amount of dye was quantified by measuring the absorbance at $\mathrm{OD}_{590}$.

Estimation of flocculation : Flocculation expressed as floc yield was carried out following the protocols of Sadasivan and Neyra (1985). Bacteria were grown at $30^{\circ} \mathrm{C}$ for $72 \mathrm{~h}$ in TSB media and flocs were harvested by filtering through Whatman filter paper (No. 1). To measure dry weight, the filter paper with the flocs was placed in a desiccator oven at $60^{\circ} \mathrm{C}$. After $2 \mathrm{~h}$, the dried filter paper was weighed and floc yield was expressed as $\mathrm{mg}$ per liter of medium $\left(\mathrm{mgl}^{-1}\right)$.

Plant growth promotion efficiency and biofilm formation under in vitro conditions: Halotolerant bacterial strains were grown in Luria-Bertani broth in a shaking incubator at $150 \mathrm{rpm}$, at $28 \pm 2{ }^{\circ} \mathrm{C}$ for $48 \mathrm{~h}$. Bacterial cells were harvested and adjusted to OD 0.5 , which corresponds to a bacterial load of $>10^{8} \mathrm{cfu} \mathrm{ml}^{-1}$. Plant growth promotion ability of halotolerant strains was studied by roll towel method (ISTA, 1993). Germination percentage was calculated on the $7^{\text {th }}$ day and vigor index $(\mathrm{VI})$ was estimated on the $14^{\text {th }}$ day, following the method of Abdul-Baki and Anderson (1983) by the following formula: $V I=G P^{*}(R L+S L)$ where, $R L$ is the root length, $S L$ is the Shoot length and $G P$ is the Germination percentage. The plant fresh weight was also measured on the $14^{\text {th }}$ day and expressed as mg plant ${ }^{-1}$. The biofilm formation on Canola root surfaces was estimated according to the methods of Fujishige et al. (2006) with required modifications. In brief, to evaluate the biofilm formation, the roots were detached and washed in sterile distilled water in an orbital shaker to remove the loosely associated cells. To evaluate the number of bacterial cells, 
about 4-5 cm of root piece was vortexed in $0.1 \mathrm{mM}$ PBS and plated on nutrient agar plates. The plant roots were stained with $0.1 \%$ aqueousalcian blue dye and observed microscopically as described by Gerhardt et al. (1981).

Statistical analysis: For statistical analysis, data were subjected to one or two way ANOVA, followed by DMRT with critical differences (C.D) calculated at $P$ level of $0.05 \%$. Regression analysis was performed with Microsoft Excel 2013 and $P$ level were calculated at $0.05,0.01$ and $0.001 \%$.

\section{Results and Discussion}

EPS production of the four halotolerant bacterial strains (B. iodinum RS16, M. yunnanensis RS222, B. aryabhattai
RS341, B. lichenifomis RS656) was evaluated in terms of dry mass and the results are presented in Fig $1 \mathrm{a}$. It was observed that the EPS content of the studied strains increased as $\mathrm{NaCl}$ concentration increased. Except for B. iodinum RS16, the highest EPS dry weight was observed in strain $B$. aryabhattai RS341at 2M $\mathrm{NaCl}$ concentration. Regression analysis between salt concentrations and EPS content of all strains were also found to be significant (Table 1). Several researchers (Qurashi and Saabri, 2012a; Zhang et al., 2013;Wang et al., 2016) reported that EPS production is a survival strategy adopted by these bacteria to tolerate high salt levels by maintaining a mini assembly to retain water level around the cells. Zaki et al. (2013) reported carbohydrate as a major component in thermo-stable bioflocculant obtained from strain Bacillus velezensis 40B.
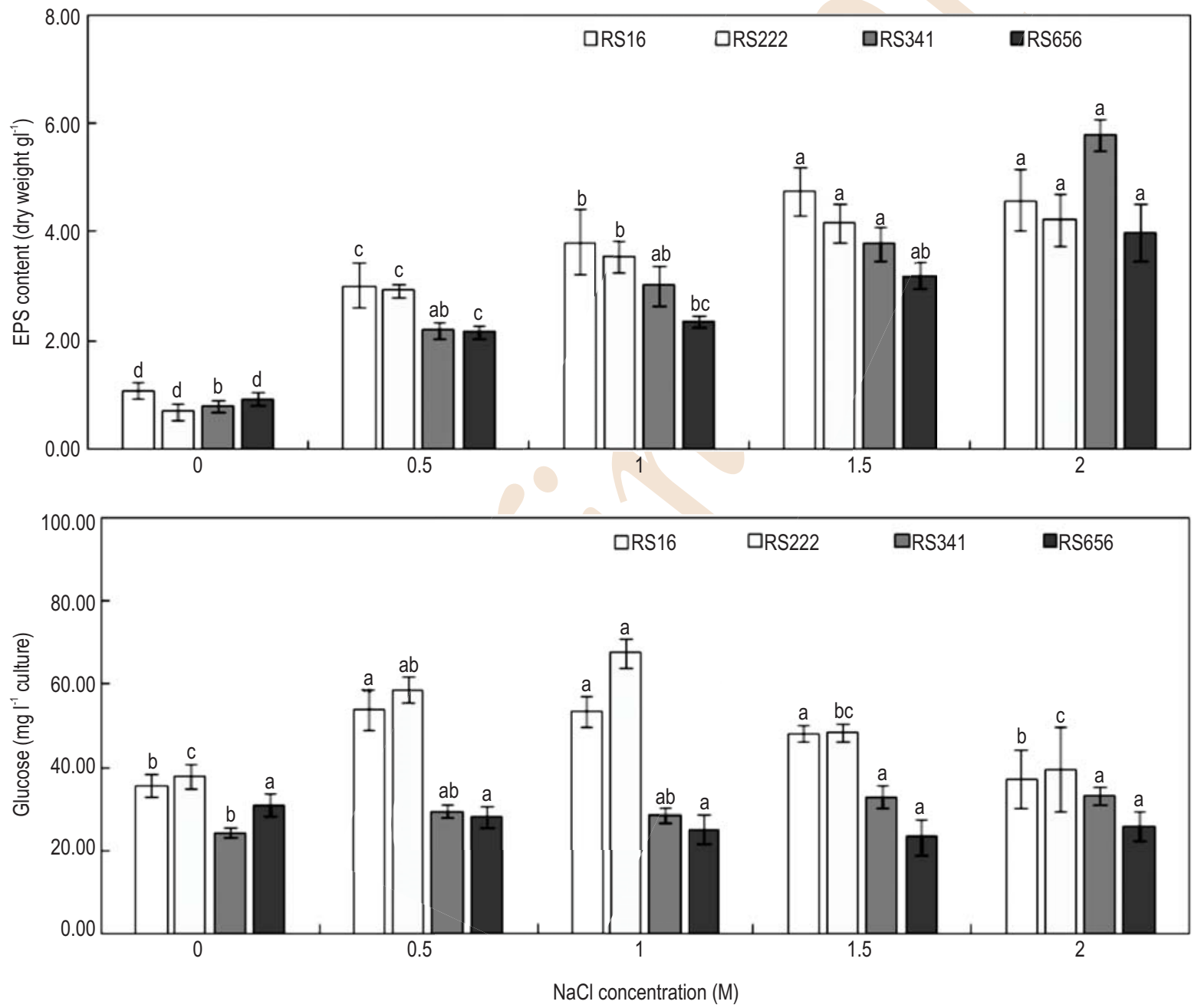

Fig. 1 : Effect of $\mathrm{NaCl}$ concentrations on (A) EPS-dry mass and (B) EPS glucose content (as glucose $\mathrm{mg} \mathrm{I}^{-1}$ culture)of halotolerant bacterial strains. Each value represents the mean of three replicates $\pm \mathrm{SE}$. Same letters in the graph are not significantly different according to $\mathrm{DMRT}$ at $P \leq 0.05$ 

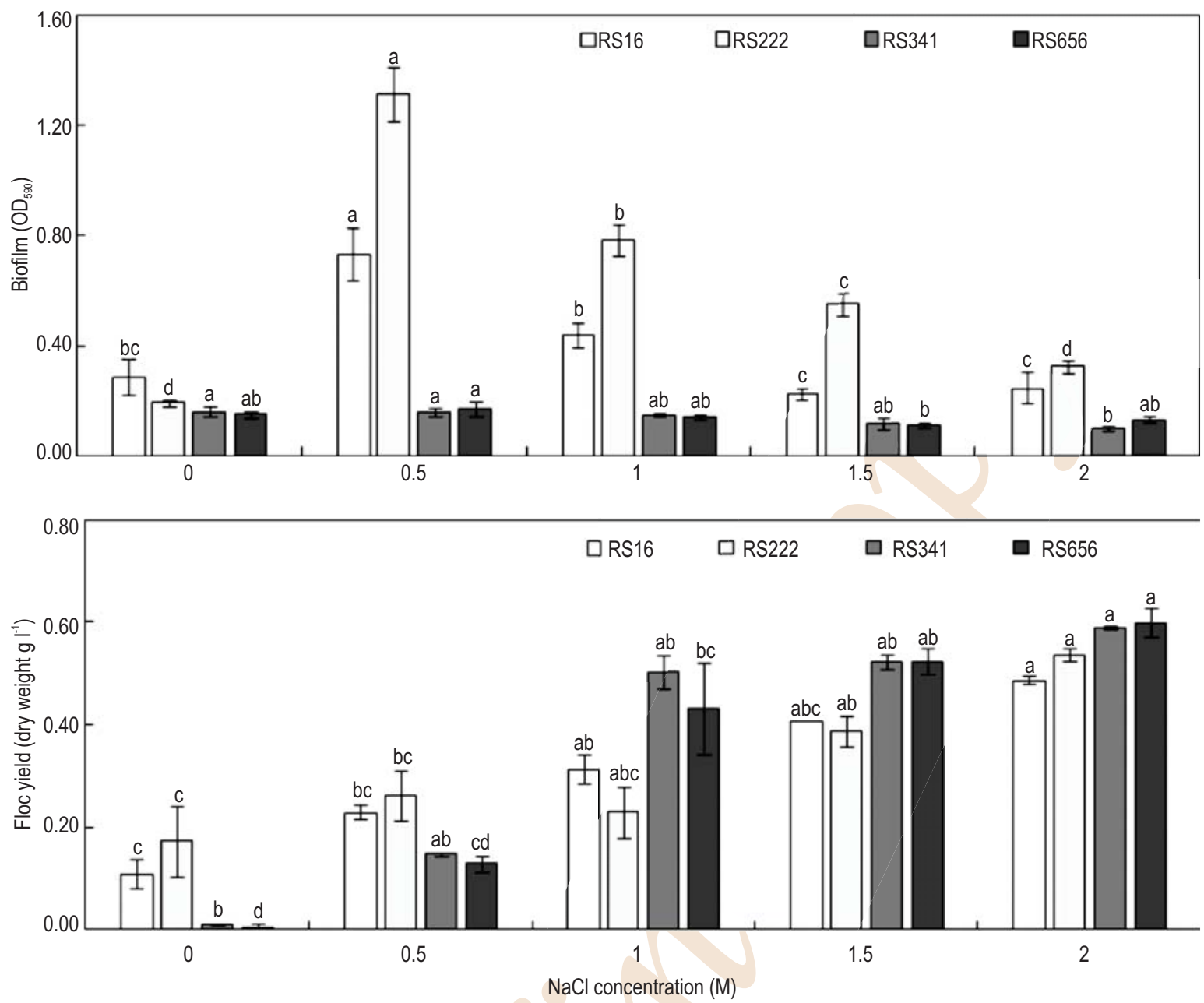

Fig. 2 : Effect of $\mathrm{NaCl}$ concentration on (A)biofilm formation of halotolerant bacterial strains; (B) flocculation, expressed in terms of floc yield, among halotolerant bacterial strains in TSB medium. Each value represents the mean of three replicates \pm SE. Same letters in the graph are not significantly different according to DMRT at $P \leq 0.05$

Table 1 : Regression analysis between salt concentration and differentEPS content, glucose content, biofilm formation and floc yield

\begin{tabular}{llllll}
\hline Parameters & \multicolumn{5}{c}{ Significance F } \\
\cline { 2 - 5 } & RS16 & RS222 & RS341 & RS656 & Overall \\
\hline EPS content & $*$ & $*$ & $* *$ & $* *$ & $* *$ \\
Glucose content & $\mathrm{ns}$ & $\mathrm{ns}$ & $*$ & $\mathrm{~ns}$ & $\mathrm{~ns}$ \\
Biofilm formation & $\mathrm{ns}$ & $\mathrm{ns}$ & $\mathrm{ns}$ & $\mathrm{ns}$ & $\mathrm{ns}$ \\
Floc. yield & $* * *$ & $*$ & $*$ & $* *$ & $* * *$ \\
\hline
\end{tabular}

${ }^{*}$ - significant at $P \leq 0.05 ;{ }^{* *}$ - significant at $P \leq 0.01$; *** - significant at $P \leq 0.001$; ns - not significant

On analyzing EPS content of the studied strains in terms of glucose content, it was observed that strain M. yunnanensis RS222 showed highest EPS-glucose content at all the studied $\mathrm{NaCl}$ concentrations (Fig. 1b). Strains B. iodinum RS16 and $M$. yunnanensis RS222 showed maximum EPS-glucose level at $1 \mathrm{M}$ $\mathrm{NaCl}$ concentration, while $B$. aryabhattai RS341 and $B$. licheniformis RS656 exhibited maximum EPS-glucose at 0 and 1.5 $\mathrm{M} \mathrm{NaCl}$ concentration, respectively. Strain M. yunnanensis RS222 


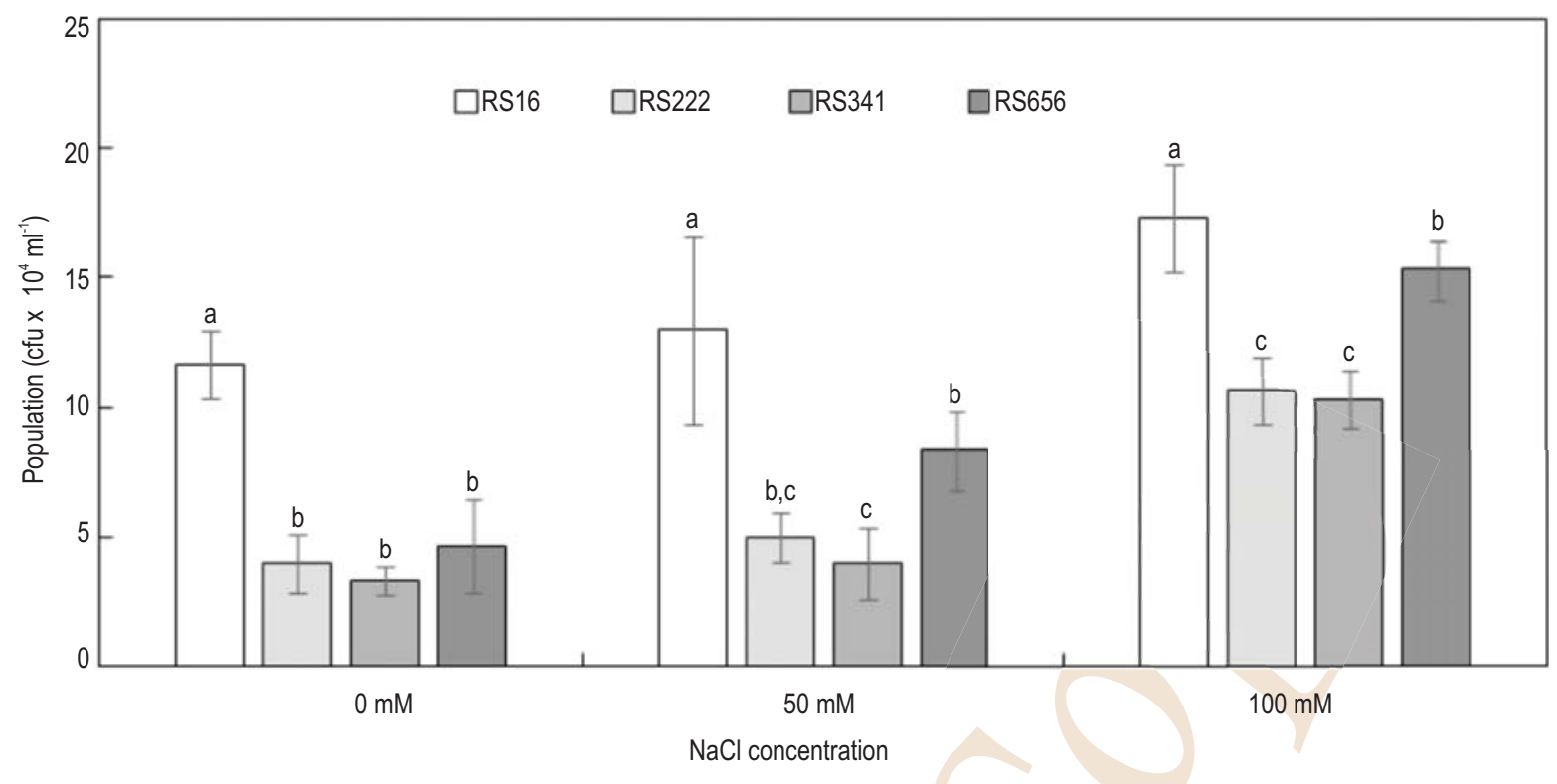

Fig. 3 : Effect of $\mathrm{NaCl}$ concentrations on bacterial biofilm, expressed in terms of CFUs, in canola (Brassica campestris L.) seedling on $15^{\text {th }}$ day. Each value represents the mean of three replicates \pm SE. Same letters in the graph are not significantly different according to DMRT at $P \leq 0.05$

showed highest EPS-glucose level of $67.32 \mathrm{mg} \mathrm{I}^{-1}$ at $1 \mathrm{M} \mathrm{NaCl}$ concentration among the studied strains (Fig. 1b) and the overall response of strain B. aryabhattai RS341 to EPS-glucose levels under salt stress was also found to be significant (Table 1).The high EPS-glucose content of these strains under different $\mathrm{NaCl}$ levels in this study is in confirmation with the earlier report of Bahat-Samet et al. (2004) where glucose was the main sugar in the EPS of A.brasilense AP7 strain during the exponential growth phase. Failure to observe overall significant differences in glucose levels under salt stress in other strains may be due to the possible involvement of other sugars in the EPS formation (Table 1). Qurashi and Sabri (2012b) and Satpute and Banat (2010) reported that the composition of EPS molecules produced by bacteria is variable with the presence of a number of sugar molecules such as glucose, galactose, mannose, xylose, glucuronic and galacturonic acids.

Biofilm formation of the bacterial strains varied under different $\mathrm{NaCl}$ concentrations based on microtiter plate assay (Fig. 2a). B. iodinum RS16, M. yunnanensis RS222, and B. lichenifomis RS656 strains showed higher biofilm formation at 0.5 $\mathrm{M} \mathrm{NaCl}$ concentration. In general, biofilm formation of the strains decreased at concentrations above $0.5 \mathrm{M} \mathrm{NaCl}$ concentration, but biofilm formation in $B$. lichenifomis RS656 increased above $1.5 \mathrm{M} \mathrm{NaCl}$ concentration. The biofilm formation of strain $M$. yunnanensis RS222 was found to be highest among all the halotolerant strains $\left(1.31, \mathrm{OD}_{590}\right)$ at $1.5 \mathrm{M} \mathrm{NaCl}$. These results are in line with the earlier finding of Rode et al.(2007), wherein $\mathrm{NaCl}$ in combination with glucose increased the biofilm formation in Staphylococcus aureus strains. This result could be explained based on the fact that biofilm formation is a strategy used by the bacteria to protect themselves from various environmental stresses (Flemming and Wingender, 2001). The reduction of biofilm formation in $B$. iodinum $\mathrm{RS} 16$ with respect to $\mathrm{NaCl}$ concentration go well with the previous studies of Martinez et al.(2011) and Havasi et al. (2008), where a decrease in growth and biofilm formation with an increase in $\mathrm{NaCl}$ concentration in the cultures of $S$. maltophilia $\mathrm{X} 26332$ and $P$. aeruginosa was reported. These authors explained that reduction of biofilm formation was due to the inhibitory role of saline in motility and growth of these bacterial strains.

A concomitant increase in floc yield was observed with increase in $\mathrm{NaCl}$ concentration in all the studied strains. The highest floc yield was observed in most of the strains at $2 \mathrm{M} \mathrm{NaCl}$ concentration (Fig. 2b), however, B. iodinum RS16 showed maximum floc yield at $1.5 \mathrm{M} \mathrm{NaCl}$ concentration. The highest floc yield of $0.60 \mathrm{gl}^{-1}$ was observed in strain $B$. licheniformis RS656 at this concentration. The overall increase in the floc yield was found to be related to the increase in $\mathrm{NaCl}$ concentration (Table 1). These results in the increase in floc yield at various $\mathrm{NaCl}$ concentration confirms with the previous report of Watanabe et al. (1998), who observed that increasing $\mathrm{NaCl}$ concentration up to $6 \%$, increased the flocculation ability in marine photosynthetic bacterium Rhodovulum sp. by $80 \%$. Jensen et al. (2007) reported the reason for this increase in flocculation to the change in adhesion pattern in Listeria monocytogenes strains in the presence of $5 \% \mathrm{NaCl}$ in TSB.

Biofilm formation of four halotolerant bacteria in the root region of canola plants was compared at 0,50 and $100 \mathrm{mM} \mathrm{NaCl}$ 

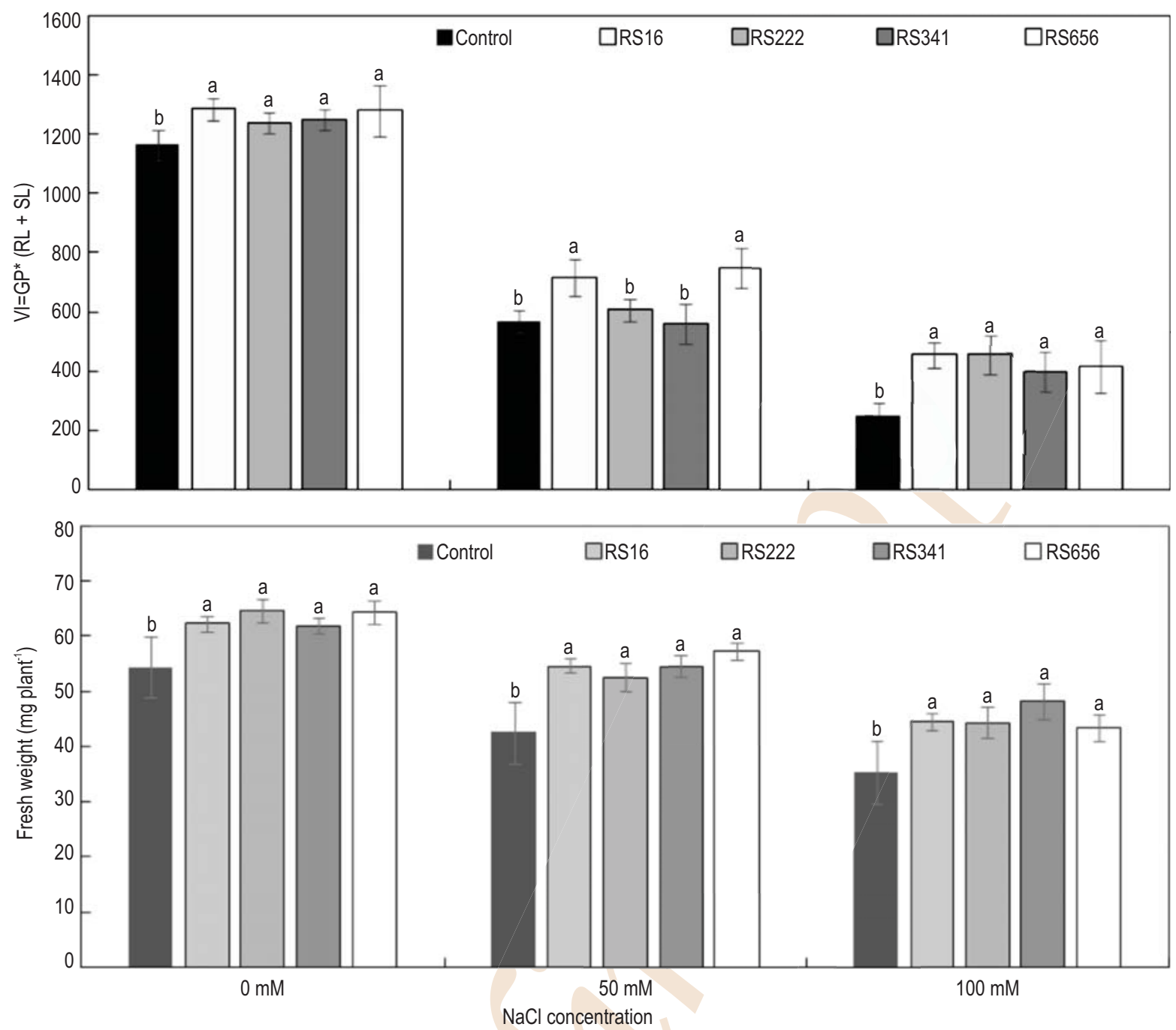

Fig. 4 : Effect of $\mathrm{NaCl}$ concentrations on (A) Vigor index of canola (Brassica campestris L.) seedlings at $0 \mathrm{mM}, 50 \mathrm{mM}$ and $100 \mathrm{mM} \mathrm{NaCl}$ concentrations on $15^{\text {th }}$ day, (B) Plant fresh weight at different $\mathrm{NaCl}$ concentration. Each value represents the mean of three replicates $\pm \mathrm{SE}$. Same letters in the graph are not significantly different according to DMRT at $P \leq 0.05$

concentrations. It was observed that the biofilm formation efficiency expressed as cfu $\mathrm{ml}^{-1}$ in all the strains increased as $\mathrm{NaCl}$ concentration increased (Fig. 3a). Strain B.iodinum RS16 showed the highest biofilm formation in all the studied $\mathrm{NaCl}$ concentrations. At highest concentration $(100 \mathrm{mM} \mathrm{NaCl})$, the highest biofilm formation of $17.3 \times 10^{4} \mathrm{Cfu} \mathrm{m}^{-1}$ was observed with $B$. iodinum RS16, and this was followed by $B$. licheniformis RS656 $\left(17.3 \times 10^{4} \mathrm{Cfu} \mathrm{ml}^{-1}\right)$. Alcian blue staining showed the presence of biofilms in all the bacterial treatments, and its absence in the control treatment (data not shown). Microscopic analysis also revealed the presence of more biofilm formation in the root tips, as compared to other root regions.
The effect of halotolerant bacteria in salt stress alleviation in canola seedlings was compared at 0,50 and $100 \mathrm{mM} \mathrm{NaCl}$ concentration for a period of 15 days. The vigor index of plants increased by10.2, 6.1, 7.2, and $9.7 \%$ in B. iodinum RS16, $M$. yunnanensis RS222, B. aryabhattai RS341 and B. licheniformis RS656 strains, respectively, compared to non-inoculated treatment at $0 \mathrm{mM} \mathrm{NaCl}$ concentration (Fig. $4 a$ ). At $50 \mathrm{mM} \mathrm{NaCl}$ concentration, only B.iodinum RS16 and B. licheniformis RS656 treated plants showed significant improvement in vigor index as compared to control. At $100 \mathrm{mM} \mathrm{NaCl}$ stress, vigor index increased by $126.6,115.2,175.4$ and $158.8 \%$ over control with inoculation of $B$. iodinum RS16, M. yunnanensis RS222, $B$. 
aryabhattai RS341 and B. licheniformis RS656, respectively. Interestingly all the halotolerant bacteria treated plants showed higher plant fresh weight as compared to control, irrespective of $\mathrm{NaCl}$ concentrations (Fig 4b).

In the plant tests, seedlings inoculated with $B$. iodinum RS16 and $B$. aryabhattai RS341 showed an increase in plant root lengths compared to control at $100 \mathrm{mM} \mathrm{NaCl}$ concentration. Previous studies (Siddikee et al., 2011; Siddikee et al., 2012; Siddikee et al., 2015) demonstrated that the plant growth promoting potential of these four halotolerant strains, improved plant growth by producing various plant hormones and stress alleviating enzymes under salinity stress.

In the present study, it is understood that the halotolerant strains exhibited high EPS production and can efficiently form biofilms, which in turn can reduce the effect of stress in plants grown under in vitro conditions.

\section{Acknowledgment}

This work was supported by the Strategic Initiative for Microbiomes in Agriculture and Food, Ministry of Agriculture (914004-4), Ministry of Agriculture, Food and Rural Affairs, Republic of Korea.

\section{References}

Abdul-Baki, A.A. and J.D. Anderson: Vigour determination in soybean seed by multiple criteria. Crop Sci., 13, 630-633 (1973).

Ashraf, M., F. Hussain and S. Hasnain: Exo-polysaccharides (eps) producing biofilm bacteria in improving physico-chemical characteristics of the salt-affected soils. Proc. First Int. Env. Sus. Dev., 36, 1527-1536 (2005).

Bahat-samet, E., S. Castrosowinski and Y. Okon: Arabinose content of extracellular polysaccharide plays a role in cell aggregation of Azospirillum brasilense. FEMS Microbiol. Lett., 237, 195-203 (2004).

Chen, Y., F. Yan, Y. Chai, H. Liu, R. Kolter, R. Losick and J.H. Guo: Biocontrol of tomato wilt disease by Bacillus subtilis isolates from natural environments depends on conserved genes mediating biofilm formation. Environ. Microbe.,15, 848-864 (2013).

Christensen, G.D., W.A. Simpson, J.J. Younger, L.M. Baddour, F.F. Barrett, D.M. Melton and E.H. Beachey: Adherence of coagulasenegative staphylococci to plastic tissue culture plates: A quantitative model for the adherence of staphylococci to medical devices. J. Clin. Microbiol. 22, 996-1006 (1985).

DuBois, M., K.A. Gilles, J.K. Hamilton, P.A. Rebers and F. Smith: Colorimetric method for determination of sugars and related substances. Anal. Chem., 28, 350-356 (1956).

De Vuyst, L., F. Vanderveken, S. Van de Ven and B. Degeest: Production by and isolation of exopolysaccharides from Streptococcus thermophilus grown in milk medium and evidence for their growthassociated biosynthesis. J. Appl. Microbiol., 84, 1059-1068 (1998).

Flemming, H.C. and J. Wingender: Relevance of microbial extracellular polymeric substances (EPSs) Part I: Structural and Ecological Aspects. Water Sci Technol., 43, 1-8 (2001).
Fujishige, N.A. and N.N. Kapadia, P.L. De-Hoff and A.M. Hirsch: Investigations of Rhizobium biofilm formation. FEMS Microbiol Ecol., 56, 195-206 (2006).

Gerhardt, P., R. G. E. Murray, R. N. Costilow, E. W. Nester, W. A. Wood, N. R. Krieg and G. Briggs Phillips: Manual of Methods for General Bacteriology. pp. 415-416 (1981).

Havasi, V., C.O. Hurst, T.C. Briles, F. Yang, D.G. Bains and D.J. Hassett: Inhibitory effects of hypertonic saline on $P$. aeruginosa motility. J. Cyst. Fibros., 7, 267-9 (2008).

ISTA (International Seed Testing Association): International rules for seed testing. Seed Sci. Tech., 4, 52-70 (1993).

Jensen, A., M.H. Larses, H. Ingmer, B.F. Vogeln and L. Gram: Sodium chloride enhances adherence and aggregation and strain variation influences invasiveness of Listeria monocytogenes strains. J. Food Prot.,70, 592-9(2007).

Nanjani, S. and H. Soni: Diversity and EPS production potential of halotolerant bacteria from veraval and Dwarka. IOSR J. Pharm. Biol. Sci., 2, 20-25 (2012).

Qurashi, A. and A. Sabri: Biofilm formation in moderately halophilic bacteria is influenced by varying salinity levels. J. Basic Microbiol., 52,566-572 (2012a)

Qurashi, A.W. and A.N. Sabri: Bacterial exopolysaccharide and biofilm formation stimulate chickpea growth and soil aggregation under salt stress. Braz. J. Microbiol., 43, 1183-1191(2012b).

Ranjbar, F. and M. Jalali: The combination of geostatistics and geochemical simulation for the site-specific management of soil salinity and sodicity. Comp. Elect. Agri., 121, 301-312 (2016).

Rode, T., S. Langsrud, A. Holck and T. Møretrø: Different patterns of biofilm formation in Staphylococcus aureus under food-related stress conditions. Int. J. Food Microbiol., 30, 372-83 (2007).

Sadasivan, L. and C.A. Neyra: Flocculation in Azospirillum brasilense and Azospirillum lipoferum: Exopolysaccharides and cyst formation. J. Bacteriol. 163, 716-723 (1985).

Satpute, S. and I. Banat: Biosurfactants, bioemulsifiers and exopolysaccharides from marine microorganisms. Biotechnol., 28, 436-50 (2010)

Siddikee, M. and B. Glick: Enhancement of growth and salt tolerance of red pepper seedlings (Capsicum annuum $\mathrm{L}$.) by regulating stress ethylene synthesis with halotolerant bacteria. Plant Physiol., 49, 427-434 (2011).

Siddikee, M., T. Chauhan and T. Sa: Regulation of ethylene biosynthesis under salt stress in red pepper (Capsicum annuum L.) by 1aminocyclopropane-1-carboxylic acid (ACC) deaminaseproducing. J. Plant Growth Regul., 31, 265-272 (2012).

Siddikee, M.A., S. Sundaram, M. Chandrasekaran, K. Kim, G. Selvakumar and T. Sa: Halotolerant bacteria with ACC deaminase activity alleviate salt stress effect in canola seed germination. J. Kor. Soc. Appl. Biol. Chem., 58, 237-241 (2015).

Tenney, M. and W. Stumm: Chemical flocculation of microorganisms in biological waste treatment. J. Water Pollut. Cont. Fed., 37, $1370-$ 1388(1965)

Tester, M. and R. Davenport: $\mathrm{Na}^{+}$tolerance and $\mathrm{Na}^{+}$transport in higher plants. Ann. Bot., 91, 503-527 (2003).

Upadhyay, S.K., J.S. Singh and D.P. Singh: Exopolysaccharideproducing plant growth-promoting rhizobacteria under salinity condition. Pedosphere, 21, 214-222 (2011).

Verhoef, R., P.D. Waard, H.A. Schols, M. Siika-aho and A.G.J. Voragen: Methylobacterium sp. isolated from a Finnish paper machine produces highly pyruvated galactan exopolysaccharide. 
Carbohydr. Res., 338, 1851-1859 (2003).

Vurukonda, S.S.K.P., S.Vardharajula and M. Shrivastava: Enhancement of drought stress tolerance in crops by plant growth promoting rhizobacteria. Microb. Res.,184, 13-24 (2016).

Wang, W., W. Liu, L. Wang, T. Yang and R. Li: Characteristics and distribution research on extracellular polymer substance extracted from sewage sludge. J. Environ. Biol., 37, 305-9 (2016).

Watanabe, M., K. Sasaki, Y. Nakashimada, T. Kakizono, N. Noparatnaraporn and N. Nishio: Growth and flocculation of a marine photosynthetic bacterium Rhodovulum sp. Appl. Microbiol. Biotechnol., 50, 682-91 (1998).

Zaki, S.A., M.F. Elkady, S. Farag and D. Abd-El-Haleem: Characterization and flocculation properties of a carbohydrate bioflocculant from a newly isolated Bacillus velezensis 40B. J. Environ. Biol., 34, 51-58 (2013).

Zhang, S.H., X.H. Zhang, L. Lv, Q. Wang and Q. Jiang: Formation of aerobic granular sludge under adverse conditions: Low DO and high ammonia. J. Environ. Biol., 34, 409-414 (2013). 